\title{
CRISPR-mediated gene modification of hematopoietic stem cells with beta- thalassemia IVS-1-110 mutation
}

\author{
Hala Gabr', Mona Kamal El Ghamrawy², Abdulrahman H. Almaeen³, Ahmed Samir Abdelhafiz ${ }^{4}$, \\ Aya Osama Saad Hassan ${ }^{1}$ and Maha Hamdi El Sissy ${ }^{1 *}$
}

\begin{abstract}
Background: $\beta$-Thalassemias represent a group of genetic disorders caused by human hemoglobin beta (HBB) gene mutations. The radical curative approach is to correct the mutations causing the disease. CRISPR-CAS9 is a novel gene-editing technology that can be used auspiciously for the treatment of these disorders. The study aimed to investigate the utility of CRISPR-CAS9 for gene modification of hematopoietic stem cells in $\beta$-thalassemia with IVS-1-110 mutation.

Methods and results: We successfully isolated $\mathrm{CD}_{3} 4^{+}$cells from peripheral blood of $\beta$-thalassemia patients with IVS-1-110 mutation. The cells were transfected with Cas9 endonuclease together with guide RNA to create doublestrand breaks and knock out the mutation. The mutation-corrected $\mathrm{CD}_{3} 4^{+}$cells were subjected to erythroid differentiation by culturing in complete media containing erythropoietin.
\end{abstract}

Conclusion: CRISPR/Cas-9 is an effective tool for gene therapy that will broaden the spectrum of therapy and potentially improve the outcomes of $\beta$-thalassemia.

Keywords: Thalassemia, CRISPR/Cas-9, Reverse hybridization, Hemoglobin beta gene mutation, Hematopoietic stem cells

\section{Background}

Mutations involving the $\beta$-globin gene are the most common cause of genetic disorders in humans. $\beta$ Thalassemia constitutes a group of hereditary disorders affecting the expression of adult $\beta$-globin gene. They are caused by a few hundred of mutations decreasing or completely negating $\beta$-globin production. As a result, adult $\alpha 2 \beta 2$ hemoglobin ( $\mathrm{HbA})$ is reduced and excess $\alpha$-globin content accumulates in the erythroid cells resulting in ineffective erythropoiesis and augmented apoptosis [20]. Besides being prevalent

\footnotetext{
* Correspondence: mahaelsissy@yahoo.com

${ }^{1}$ Clinical and Chemical Pathology, Faculty of Medicine, Cairo University, Cairo, Egypt

Full list of author information is available at the end of the article
}

among Africans, $\beta$-thalassemias are also common in Greeks and Italians [30]. It has been estimated that 1000 children out of 1.5 million live births are born annually with thalassemia major in Egypt [11]. In Egyptian multi-centric studies, the carrier rate has been reported to be in the range of $9-10 \%$ [9]. The more than $350 \beta$-thalassemia mutations reported are geographically widely diverse with a small number of specific mutations in individual populations. Thalassemia syndromes are common in Saudi Arabia. Betathalassemia gene mutations, particularly $\mathrm{B}^{+}$and $\mathrm{B}^{\circ}$ thalassemia, occur with variable frequency in different regions of Saudi Arabia [6].

Thalassemia therapy constitutes a major socioeconomic burden. Various methods of treatment have been 
attempted, yet they have not been efficiently successful till now. Recently, the technology of clustered regularly interspaced short palindromic repeats (CRISPR)-based DNA editing has emerged as an encouraging tool to rectify genetic abnormalities in thalassemias [12]. Cas9 (CRISPR-associated protein-9 nuclease) is an RNAguided endonuclease that utilizes RNA-DNA base pairing to spot target genomic DNA. Bound to its target via the guide RNA (gRNA), Cas9 generates DNA double-strand breaks (DSBs) at the pre-specified genomic sites that instantaneously activate the endogenous DNA repair mechanisms [22]. DSB repair is accomplished by either non-homologous end joining (NHEJ) or homology-directed repair (HDR; specific to S and G2 phases of dividing cells where sister chromatids exist). CRISPR/cas-9 genome editing system is a promising, feasible and safe approach for treating hemoglobinopathies or thalassemia given its efficiency [34].

The aim of this study was to assess the utility of CRIS PR/Cas9 technology in correcting the $H B B$ gene mutations in $\mathrm{CD}^{+}{ }^{+}$cells collected from $\beta$-thalassemia patients with the Mediterranean cryptic splice site IVS$1-110(\mathrm{G} \rightarrow \mathrm{A})$ mutation.

\section{Methods}

\section{Patients}

The study was conducted on six pediatric $\beta$-thalassemia patients with IVS-1-110 mutation. The patients' custodians accepted to participate in the current study by signing a written consent. Patients were selected from Hematology Clinic of Abul-Reesh Mounira Children's Hospitals, Cairo University, Cairo, Egypt. They were diagnosed as $\beta$-thalassemia by routine work-up and history including age, consanguinity, and blood transfusion. The research was approved by the ethical committee of the Clinical Pathology and the Pediatrics Departments, Kasr Alainy Hospitals, Cairo University.

Relevant demographic data of the patients were collected and a complete clinical examination was done with attention to the pallor, mongoloid faces, and the size of the liver and spleen. Investigations including complete blood count using an automated cell counter (Cell Dyne, USA), reticulocyte count using brilliant cresyl blue, $\mathrm{Hb}$ electrophoresis, and genotyping of $\beta$ thalassemia globin gene mutation by reverse hybridization technique were done for all patients.

\section{Methods}

\section{Separation of mononuclear cells from human peripheral} blood

This separation was aseptically done by gradient centrifugation using Ficoll Hypaque according to the method of [39]. Briefly, heparinized blood samples were carefully suspended in $5 \mathrm{~mL}$ of $60 \%$ Ficoll Hypaque separation solution in a sterile conical tube, centrifuged for 20-25 $\min$ at $2000 \mathrm{rpm}$ at $8^{\circ} \mathrm{C}$. The mononuclear cells were retrieved from the buffy coat layer by sterile Pasteur pipette, washed three times with phosphate-buffered saline (PBS), and centrifuged at $2000 \mathrm{rpm}$ for $20 \mathrm{~min}$. Cells were counted using automated cell counter (Cell Dyne, Inc., USA).

\section{Magnetic separation of $\mathrm{CD} 34^{+}$cells from mononuclear cells with the auto-MACS separator}

Cell population evaluation by the expression of CD34 marker was done as a functional assay to prove the cells are indeed HSC. Performing functional assays such as clonogenic ability (CFU formation in semisolid culture) can be done in a subsequent expansion of the work.

Cells were re-suspended in PBS, and anti-CD34 monoclonal antibody is added and mixed well followed by incubation for $10 \mathrm{~min}$ in the dark in the refrigerator. Then they were washed and resuspended in the buffer, and the anti-PE MicroBeads are added. Cells were subjected to magnetic separation on MACS separator.

\section{Cas9 transfection, cell culturing, and induction of the erythroid differentiation}

Cas9 protein bound to the guide RNA were non-virally transfected using the calcium phosphate method. Specified by the target DNA sequence, two $H B B$ gene-based gRNA candidates were selected and the sequences of each gRNA candidate/name of the source plasmid are (1) GTAACGGCAGACTTCTCCTCNGG/HBB.g14 and CTTGCCCCACAGGGCAGTAANGG/ HBB.g13, respectively; the Proto-spacer Adjacent Motif (PAM) site is in bold.

\section{Preparation of selective media and determining puromycin concentration}

The kill dose-response curve was used to determine the antibiotic concentration sufficient to kill all of the nontransfected cells in 4 days duration. Calcium phosphate transfection [40] and erythroid culture were accomplished. Functional assay for erythroid progenitors was done:

- Morphology: appearance of BFU-E colonies in semisolid culture (Fig. 1)

- Hemoglobin synthesis: RNA extraction of betaglobin gene from cultured erythroid progenitors and further identification of the presence or absence of beta-globin mutations

Genomic DNA extraction using PureLink ${ }^{\mathrm{Tm}}$ Genomic DNA Mini Kit was done according to the manufacturer's instructions. This was followed by an evaluation of the 


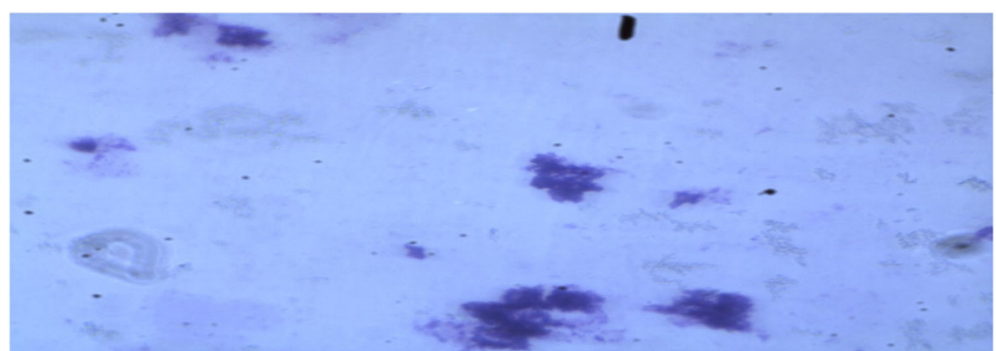

Fig. 1 Functional assay of peripheral blood patient-derived hematopoietic stem cells (HSCs) under an inverted microscope at day 17 of culture differentiated into erythroid precursors (BFU-E colonies in semisolid cultures) under the effect of erythropoietin, trypan blue staining (high-power magnification $\times 40$ )

$\beta$-globin gene product by PCR for normal and aberrant DNA (IVS-1-110) in the erythroid cultured cells.

\section{Polymerase chain reaction (PCR)}

All PCR reactions were done in $25 \mu \mathrm{L}$ volume using: Master Mix (GeneON), forward (5-TAATACGACT CACTATAGGG-3') and reverse primers (5'-CCTCGA CTGTGCCTTCTA-3'), and the extracted genomic DNA. The thermocycler program applied comprised initial denaturation at $94^{\circ} \mathrm{C}$ for $2 \mathrm{~min}, 35$ cycles of denaturation at $94{ }^{\circ} \mathrm{C} / 15 \mathrm{~s}$, annealing at $58^{\circ} \mathrm{C} / 30 \mathrm{~s}$ and extension at $72{ }^{\circ} \mathrm{C} / 45 \mathrm{~s}$, and a final extension at $72{ }^{\circ} \mathrm{C} / 3 \mathrm{~min}$.

\section{Detection of $\beta$-globin gene mutation by PCR and reverse hybridization}

PCR amplification products were detected using gel electrophoresis and were visualized on UV transillumination looking for bands with 310, 381, and $755 \mathrm{bp}$ sizes. This was followed by detection by hybridization of amplification products to a test strip containing allele- specific oligonucleotide probes immobilized as an array of parallel lines ( $\beta$-globin strip assay, Vienna Lab). The genotype of the sample was determined using the enclosed Collector $^{\mathrm{Tm}}$ sheet.

\section{Results}

The relevant demographic data of the investigated $\beta$ thalassemia pediatric patients and their laboratory findings are presented in Table 1.

$\mathrm{CD} 4^{+}$cells were isolated and evaluated. Table 2 presents the efficiency of the yield of $\mathrm{CD} 34^{+}$cells among the investigated patients. The highest yield of $\mathrm{CD}_{3} 4^{+}$ cells was in case 4 , in which there was near $94 \% \mathrm{CD}^{+} 4^{+}$ cell retrieval success.

Determination of the antibiotic kill-dose response curve that showed a minimal concentration of antibiotic that efficiently killed all non-transfected/transduced cells after treatment for up to 6 days was found to be $12 \mu \mathrm{g} /$ $\mathrm{mL}$ (Table 3).

Table 1 Demographic and laboratory data of the investigated pediatric $\beta$-thalassemia patients

\begin{tabular}{|c|c|c|c|c|c|c|}
\hline Variable & Case 1 & Case 2 & Case 3 & Case 4 & Case 5 & Case 6 \\
\hline Age (years) & 10 years & 8 years & 2 years & 1.5 years & 4 years & 3 years \\
\hline Gender & Male & female & Female & Male & Female & Male \\
\hline Duration of blood transfusion & 8 years & 7 years & 1.5 years & 1 year & 3 years & 2.5 years \\
\hline $\operatorname{RBCs}\left(\times 10^{6} / \mathrm{mm}^{3}\right)$ & 3 & 3.2 & 3.8 & 4.1 & 3.2 & 4.6 \\
\hline $\mathrm{Hb}(\mathrm{g} / \mathrm{dL})$ & 8.5 & 9.2 & 9.5 & 10.1 & 9.4 & 9.2 \\
\hline Hematocrit (\%) & 28.9 & 30.2 & 30.9 & 30.4 & 29.5 & 30.2 \\
\hline MCV (fL) & 70.5 & 69.6 & 71.4 & 65.4 & 72.4 & 74.6 \\
\hline $\mathrm{MCH}(\mathrm{pg})$ & 25.4 & 22.4 & 25.6 & 24.6 & 26.1 & 25.9 \\
\hline $\mathrm{MCHC}(\mathrm{g} / \mathrm{dL})$ & 30.8 & 32.8 & 32.6 & 30.9 & 33.1 & 30.6 \\
\hline RDW (\%) & 18.6 & 17.5 & 16.9 & 17.5 & 18.4 & 18.6 \\
\hline $\operatorname{TLC}\left(\times 10^{3} / \mathrm{mm}^{3}\right)$ & 15.5 & 20.6 & 14.6 & 17.6 & 14.9 & 25.6 \\
\hline Platelets $\left(\times 10^{3} / \mathrm{mm}^{3}\right)$ & 466 & 522 & 416 & 650 & 578 & 563 \\
\hline Reticulocytes (\%) & 6.5 & 5.4 & 10.2 & 8 & 4.5 & 5.5 \\
\hline Serum iron $(\mu \mathrm{g} / \mathrm{dL})$ & 80 & 61 & 102 & 95 & 67 & 90 \\
\hline $\mathrm{HbF}(\%)$ & 80.2 & 84.6 & 74.02 & 66.4 & 70.2 & 88.4 \\
\hline
\end{tabular}


Table 2 Percent retrieval of CD34+ cells from the investigated pediatric $\beta$-thalassemic patients

\begin{tabular}{|c|c|c|c|c|c|c|}
\hline \multirow[t]{2}{*}{ Case } & \multicolumn{2}{|c|}{ CD34+ cells before separation } & \multicolumn{2}{|c|}{ CD34+ cells after separation } & \multirow{2}{*}{$\begin{array}{l}\text { Total } \\
\text { mononuclear } \\
\text { cell count }\end{array}$} & \multirow{2}{*}{$\begin{array}{l}\% \\
\text { retrieval } \\
\text { of } \\
\text { CD34+ } \\
\text { cells }\end{array}$} \\
\hline & Absolute count & Cells \% & Absolute count & Cells \% & & \\
\hline Case 1 & 1120 & 2.0 & 1000 & 90 & $56 \times 10^{3}$ & $89.2 \%$ \\
\hline Case 2 & 2700 & 3.2 & 2500 & 92 & $85 \times 10^{3}$ & $92.5 \%$ \\
\hline Case 3 & 1110 & 3.0 & 1000 & 87 & $37 \times 10^{3}$ & $90 \%$ \\
\hline Case 4 & 3210 & 2.2 & 3000 & 95 & $146 \times 10^{3}$ & $93.4 \%$ \\
\hline Case 5 & 2250 & 3.0 & 2000 & 90 & $75 \times 10^{3}$ & $88.8 \%$ \\
\hline Case 6 & 1300 & 2.0 & 1000 & 91 & $65 \times 10^{3}$ & $77 \%$ \\
\hline
\end{tabular}

\section{Characterization of cultured erythroid cells}

Differentiation of peripheral blood-derived CD34 ${ }^{+}$cells into erythroid precursors in serum-free medium was induced by erythropoietin (EPO). Starting from day 7, morphologically homogeneous erythroid progenitors were expanded into mass cultures in a quick time. Nonerythroid progenitors ceased their development secondary to the absence of necessary cytokines to support their proliferation and differentiation. On the other hand, erythroid progenitors were allowed to proliferate and differentiate into erythroid precursors under the effect of EPO (Fig. 1). Viability was assessed by calculating the percentage of viable cells after the addition of trypan blue vital stain.

Cell growth was quantitated by counting the cell number with a cell counter (Sysmex, Siemens). The maximum fold increase in proliferation, among the transfected cells, was observed for cells derived from case 2 (14-folds), whereas the least proliferation rate was recorded for cells derived from cases 1 and 6 (both 5folds) (Table 4).

\section{Molecular evaluation}

PCR and gel electrophoresis PCR amplicons of the $H B B$ gene of the CRISPR/Cas9-edited cells and the unedited cells were electrophoretically separated on $1.5 \%$ agarose gel. The target $381 \mathrm{bp}$ and $755 \mathrm{bp}$ size amplicons

Table 3 Dose-dependent percentage of non-transfected cell viability after treatment with different concentrations of puromycin for up to 6 days

\begin{tabular}{ll}
\hline Puromycin concentration & Non-transfected cell viability $\%$ \\
\hline $0 \mu \mathrm{g} / \mathrm{mL}$ & 100 \\
$3 \mu \mathrm{g} / \mathrm{mL}$ & 100 \\
$6 \mu \mathrm{g} / \mathrm{mL}$ & 85 \\
$9 \mu \mathrm{g} / \mathrm{mL}$ & 30 \\
$12 \mu \mathrm{g} / \mathrm{mL}$ & 0 \\
$15 \mu \mathrm{g} / \mathrm{mL}$ & 0 \\
\hline
\end{tabular}

were observed only in the edited cells but not in the control unedited cells (Fig. 2).

Reverse hybridization PCR amplicons of the $H B B$ gene of the CRISPR/Cas9 edited cells vs. the unedited control cells were subjected to reverse hybridization using $\beta$ globin strip to assess the presence of mutation. The mutation disappeared in the transfected cells that gained the wild-type gene sequence (Fig. 3).

Discussion Thalassemias represent a heterogeneous group of inherited disorders that affect synthesis of the different globin chains [16]. According to a World Health Organization (WHO) report, "approximately 5\% of the world's population carries gene traits for hemoglobin disorders; mainly sickle cell anemia (SCA) and $\alpha$ - or $\beta$-thalassemias" [41]. The latter is one of the most prevalent hereditary diseases worldwide [2]. Genetic mutations causing $\beta$-thalassemia may lie within the $\beta$-globin gene or externally within the globin locus. Point mutations constitute the majority of genetic lesions implicated in the pathogenesis of $\beta$-thalassemia. In $\beta$-thalassemia, A few hundred mutations have been described affecting a wide range of gene processes that include transcription, mRNA splicing/posttranscriptional processing, RNA stability and translation, and globin peptide stability [16]. The splicing mutation in intron 1 of $\beta$-globin gene (IVS-1-110) is the most common mutation in Egyptian thalassemics, causing an aberrant splicing of pre-mRNA and deficient synthesis of $\beta$-globin chain [10].

Although the ultimate treatment for $\beta$-thalassemia is hematopoietic stem cell transplantation (HSCT), this option is only accessible to a minority of patients due to dearth of matched donors. Moreover, HSCT is a tough treatment associated with high morbidity [28] that has been ameliorated with the increasing use of nonmyeloablative conditioning therapy [16].

Gene correction utilizing a patient's autologous stem cells is considered a great progress that overcomes tissue matching and decreases the incidence of the associated 
Table 4 Fold increase in cell number after erythroid liquid culture of transfected cells

\begin{tabular}{|c|c|c|c|c|c|}
\hline \multirow[t]{2}{*}{ Case } & \multirow{2}{*}{$\begin{array}{l}\text { Initial } \\
\text { input, } \\
\text { cell/ } \\
\mathrm{mL}\end{array}$} & \multicolumn{2}{|c|}{ Non-transfected cells after culture } & \multicolumn{2}{|c|}{ Transfected cells after culture } \\
\hline & & Number & Fold increase & Number & Fold increase \\
\hline Case 1 & 200 & 800 & 4 & 1000 & 5 \\
\hline Case 2 & 500 & 1000 & 2 & 7000 & 14 \\
\hline Case 3 & 200 & 800 & 4 & 2400 & 12 \\
\hline Case 4 & 600 & 1000 & 1.6 & 5000 & 8.3 \\
\hline Case 5 & 400 & 900 & 2.25 & 4500 & 11.2 \\
\hline Case 6 & 200 & 1000 & 5 & 1000 & 5 \\
\hline
\end{tabular}

morbidity and mortality from allogeneic HSCT [16]. CRISPR/Cas9 represents one of the most promising tools in gene editing [34]. Gene therapy of $\beta$-thalassemia can fall into one of 4 categories: (1) gene addition, (2) gene knockdown to improve the $\beta$-globinopathy phenotype, (3) globin gene editing, and (4) gene editing of globin regulatory elements [19]. Three different systems for specific DNA cleavage to promote efficient homologous recombination have been introduced: ZFNs, TALENs, and CRISPR/Cas9 [42]. ZFNs are demanding in terms of design and cost. TALENs necessitate making numerous pairs to test their cutting efficiencies. In addition, DNA methylation and histone acetylation may affect their efficiency $[23,26,31,33]$. In comparison, the CRISPR/Cas9 is not amenable to those limitations, feasible, and easily prepared [21].

This study assessed the utility of CRISPR/Cas9 in directly targeting IVS-1-110 mutation site in $H B B$ locus, which prevails among $\beta$-thalassemic Egyptians. Our findings support the prospect of $\beta$-thalassemia gene correction using such a promising technology. The study included 6 patients diagnosed with $\beta$-thalassemia selected from the Hematology Clinic, Abou-El-ReeshMounera Children's Hospitals, Cairo University, with homozygous IVS-1.110 mutation as diagnosed by reverse hybridization using $\beta$-globin strip assay (Vienna Lab). Peripheral blood CD34 ${ }^{+}$hematopoietic stem cells were isolated by MACS method with high purity and yield of more than $90 \%$. The presence of microbeads at the surface of the separated CD $34^{+}$cells did not appear to have any negative influence on hematopoietic recovery, proliferation, homing, or the side-effects following re-infusion into patients. These findings are in agreement with [8] and Traxler et al. [36], who obtained and enriched $\mathrm{CD}^{+} 4^{+}$cells by immunomagnetic bead selection using an Auto-MACS technique (Miltenyi Biotec, Germany). Tomlinson et al. [35] reported that MACS separation is quicker than FACS straining, where a greater number of cells can be processed at one time. MACS does not require a rather expensive dedicated instrumentation. On the downside, multi-marker selection and simultaneous sorting of different populations are limitations of the MACS method [27, 29].

Compatible with the protocol done by Traxler et al. [36], our study adopted the three-phase erythroid differentiation protocol of $\mathrm{CD}_{3} 4^{+}$hematopoietic stem and progenitor cells (HSPCs): phase 1 (days $0-7$ ), phase 2 (days $8-12$ ), and phase 3 ( $\geq 13$ days). We successfully

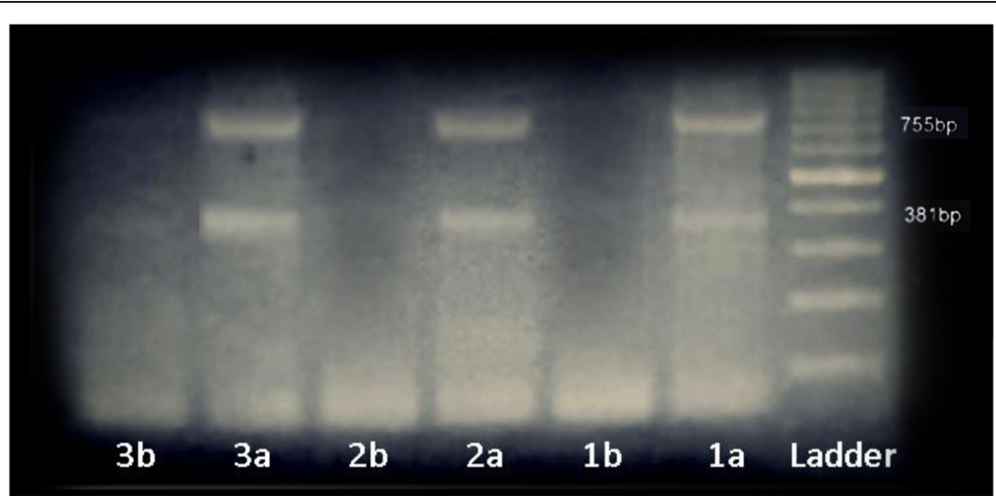

Fig. 2 Gel electrophoresis of the HBB gene-amplified PCR products. Lanes 1a, 2a, and 3a represent CRISPR/Cas9 edited cells and show bands at $381 \mathrm{bp}$ and $755 \mathrm{bp}$ size which correspond to the target amplification product as instructed by the manufacturer protocol. Lanes $1 \mathrm{~b}, 2 \mathrm{~b}$, and $3 \mathrm{~b}$ represent the control unedited cells. They show no bands 


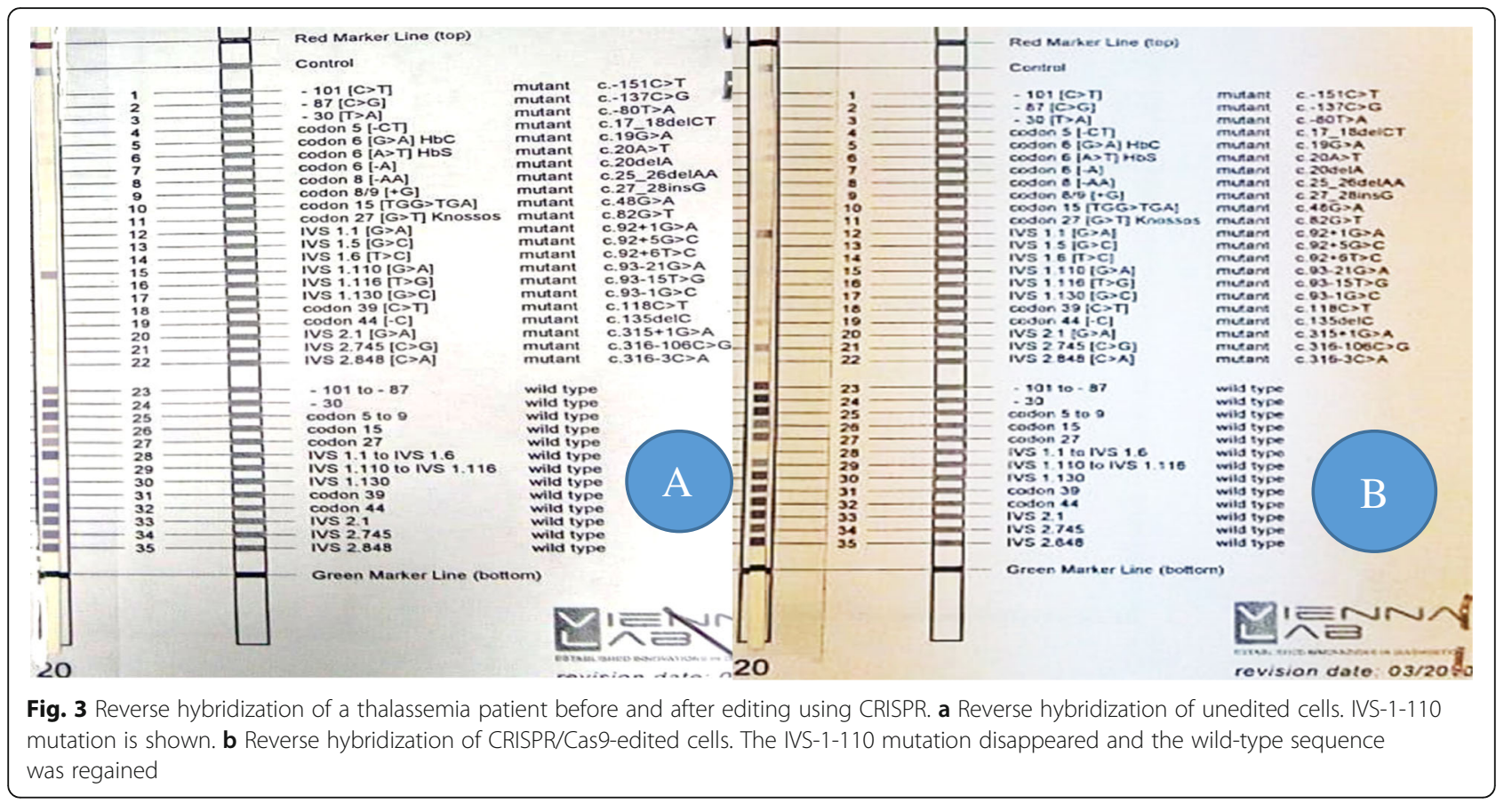

transfected the isolated $\mathrm{CD}^{+} 4^{+}$cells with gRNA/Cas9 complex non-virally using the calcium phosphate transfection method. This avoids the viral immunogenicity and cytotoxicity, with relative feasibility and higher DNA carrying capacity [1]. Actually, numerous previous studies used the inorganic calcium as a non-viral vector for nucleic acid transfection [15, 24, 25].

In our study, the CRISPR/Cas9-edited cells showed the acquisition of the wild-type gene at IVS-1.110 position which was absent in the untreated control cells, although another region of the gene was affected at IVS-1-1 locus due to the natural high rate of indel formation associated with NHEJ repair. Coetzer [3] showed that $\beta$-globin gene correction through HDR in CD34 ${ }^{+}$HSPCs using CRISPR/Cas9 and a wild-type gene donor sequence is relatively inefficient since these cells are quiescent-as HDR process is restricted to $\mathrm{S}$ and $\mathrm{G} 2$ phases of the cell cycle when sister chromatids are available as repair templates. In addition, our results are in agreement with Genovese [14] who concluded that HSCs are more resistant to HDR-mediated editing. However, homology-mediated end joining may be facilitated by the predominance of 13-nt deletion resulted from the cleavage site of Cas9 when flanked by 8 -nt tandem repeats [37]. The use of gRNA for the normal template may overcome this obstacle by inducing HDR which inserts the desired sequences through recombination of the target locus with exogenously supplied DNA donor templates [32].
Similar to previous pioneering reports, our study confirmed the utility of CRISPR/Cas9 gene editing to correct mutations that cause hemoglobinopathies and thalassemias. They showed that CRISPR/Cas9 system could correct $H B B$ gene mutations in cells isolated from hemoglobinopathic/thalassemic patients $([4,5,7,13,18$, $21,17])$. The edited HSPCs that differentiate into erythrocytes express wild-type mRNA from the endogenous $H B B$ promoter [38].

\section{Conclusion}

CRISPR/Cas9 system is a promising tool for the nextgeneration gene-editing therapy of thalassemias. In this work, the CRISPR-Cas9 system was able to specifically target the HBB gene sequence and cleavage it. This promoted efficient homologous recombination and acquisition of wild-type HBB mRNA in the transfected cells. Our results represent an addition to the existing evidence for the utility of this as a radical treatment for thalassemias and hemoglobinopathies. More studies should be carried out to refine the gene-editing process and to minimize potentially harmful off-target mutations before human clinical trials are considered.

\section{Abbreviation}

CRISPR: Clustered regularly interspaced short palindromic repeats; DNA: Deoxyribonucleic acid; DSB: Double-strand breaks; EPO: Erythropoietin; HbA: Adult hemoglobin; Hb: Hemoglobin; HBB: Hemoglobin B; HDR: Homology-directed repair; HSCPC: Hematopoietic stem and progenitor cells; HSCT: Hematopoietic stem cell transplantation; IVS: Intervening sequence; MACS : Magnetic activated cell sorting; MCH: Mean corpuscular hemoglobin; MCHC: Mean corpuscular hemoglobin concentration; 
MCV: Mean corpuscular volume; NHEJ: Non-homologous end joining: ORF: Open reading frame; PAM: Proto-spacer Adjacent Motif; PBS: Phosphate-buffered saline; PCR: Polymerase chain reaction; RBCs: Red blood cells; RDW: Red cell distribution width; RNA: Ribonucleic acid; SCA: Sickle cell anemia; TALEN: Transcription activator-like effector nuclease; TLC: Total leucocytic cells; WHO: World Health Arganization; ZFN: Zinc finger nuclease

\section{Acknowledgements}

Not applicable.

\section{Authors' contributions}

$\mathrm{HG}$ analyzed and interpreted the patient data regarding the hematological disease and the transplant. MS performed the flowcytometry analysis and was a major contributor in writing the manuscript. AO helped in writing the manuscript. MK helped in patient selection. All authors read and approved the final manuscript

\section{Funding}

Self-funded research

\section{Availability of data and materials}

All data generated or analyzed during this study are included in this published article.

\section{Ethics approval and consent to participate}

The research was approved by the ethical committee of the Clinical Pathology and the Pediatrics departments, Kasr Alainy Hospitals, Cairo University. The patients' custodians accepted to participate in the current study by signing a written consent.

\section{Consent for publication}

A written consent concerning data publication was received from patients' custodian.

\section{Competing interests}

The authors declare that they have no competing interests.

\section{Author details}

'Clinical and Chemical Pathology, Faculty of Medicine, Cairo University, Cairo, Egypt. ${ }^{2}$ Pediatric, Faculty of Medicine, Cairo University, Cairo, Egypt. ${ }^{3}$ Pathology Department, Jouf University, Sakakah, Saudi Arabia. ${ }^{4}$ Clinical Pathology, National Cancer Institute, Cairo University, Cairo, Egypt.

Received: 24 February 2020 Revised: 19 May 2020 Accepted: 5 August 2020 Published online: 10 September 2020

\section{References}

1. Cao X, Deng WW, Wei Y, Su WY, Yang Y, Wei YW, Yu JN, Xu XM Encapsulation of plasmid DNA in calcium phosphate nanoparticles: stem cell uptake and gene transfer efficiency. Int J Nanomedicine. 2011;6:333549.

2. Cao A, Kan YW. The prevention of thalassemia. Cold Spring Harbor Perspectives in Medicine. 2013;3(2):a011775.

3. Coetzer T. CRISPR-Cas9 Genome Editing: A New Era in Characterizing and Treating Hematologic Disease. Hematologist. 2017;14(1):1-3.

4. Cong L. Multiplex genome engineering using CRISPR/Cas systems. Science. 2013;339:819-23.

5. Deltcheva E, Chylinski K, Sharma CM, Gonzales K, Chao Y, Pirzada ZA. CRISPR RNA maturation by trans-encoded small RNA and host factor RNase III. Nature. 2011:471:602-7.

6. De Sanctis V, Kattamis C, Canatan D, Soliman AT, Elsedfy H, Karimi M, Daar $S$, et al. $\beta$-Thalassemia distribution in the old world: an ancient disease seen from a historical standpoint. Mediterr J Hematol Infect Dis. 2017;9(1): e2017018.

7. Deveau H, Garneau JE, Moineau S. CRISPR/Cas system and its role inphagebacteria interactions. Annu Rev Microbiol. 2010;64:475-93.

8. Diogo M, Silva $C L$, Cabral J. Separation technologies for stem cell bioprocessing. Biotechnol Bioeng. 2012;109(11):2699-709.
9. Elhalfawy Kh, Daif A, and, Shaalan O. Detection of common beta thalassemia mutations among Egyptian patients. Egyptian J Genet Cytol, 2017; 46(1): 111-119.

10. El-Beshlawy A, Mostafa A, Youssry I, Gabr H, Mansour IM, El-Tablawy M, Aziz $\mathrm{M}$, et al. Correction of aberrant pre-mRNA splicing by antisense oligonucleotides in b-thalassemia Egyptian patients with IVSI-110 mutation. J Pediatr Hematol Oncol. 2008;30(4):281-4.

11. El-Hashemite N, Petrou M, Khalifa AS, Heshmat NM, Rady MS, Delhanty JD. Identification of novel Asian Indian and Japanese mutations causing $\beta$ thalassemia in Egyptian population. Hum Genet. 1997;99(2):271-4.

12. Kim EJ, Kang KH, Ju JH. CRISPR-Cas9: a promising tool for gene editing on induced pluripotent stem cells. Korean J Intern Med. 2017a;32(1):42-61.

13. Gasiunas G, Barrangou R, Horvath P, Siksny V. Cas9-crRNA ribonucleoprotein complex mediates specific DNA cleavage for adaptive immunity in bacteria. Proc Natl Acad Sci USA. 2012;109(39):E2579-86.

14. Genovese P. Targeted genome editing in human repopulating haematopoietic stem cells. Nature. 2014:510:235-40.

15. Giger EV, Castagner B, Räikkönen J, Mönkkönen J, Leroux J. siRNA transfection with calcium phosphate nanoparticles stabilized with PEGylated chelators. Adv Healthc Mater. 2013;2(1):134-44.

16. Goodman MA, Malik P. The potential of gene therapy approaches for the treatment of hemoglobinopathies: Achievements and challenges. Ther Adv Hematol. 2016;7(5):302-15.

17. Hsu PD, Lander ES, Zhang F. Development and applications of CRISPR-Cas9 for genome engineering. Cell. 2014;157(6):1262-78.

18. Jinek M, Chylinski K, Fonfara I, Hauer M, Doudna JA, Charpentier E. A programmable dual-RNA-guided DNA endonuclease in adaptive bacterial immunity. Science. 2012;337:816-21.

19. Kleinstiver B, Pattanayak V, Prew M, Tsai S, Nguyen N, Zheng Z. High-fidelity CRISPR-Cas9 nucleases with no detectable genomewide off-target effects. Nature. 2016;529:490-5.

20. Kountouris $\mathrm{P}$, Lederer CW, Fanis $\mathrm{P}$, Feleki X, Old J, Kleanthous M. An interactive database for haemoglobin variations and epidemiology. PLoS One. 2014;9:e103020

21. Ma N, Liao B, Zhang H, Wang L, Shan Y, Xue Y, Huang K, Chen S, Zhou X, Chen $Y$. Transcription activator-like effector nuclease (TALEN)-mediated gene correction in integration-free $\beta$-thalassemia induced pluripotent stem cells. J Biol Chem. 2013;288:34671-9.

22. Ma N, Shan Y, Liao B, Kong G, Wang C, Huang K, Zhang H, et al. Factorinduced reprogramming and zinc finger nuclease-aided gene targeting cause different genome instability in beta-thalassemia induced pluripotent stem cells (iPSCs). J Biol Chem. 2015;290:12079-89.

23. Miller JC, Holmes MC, Wang J, Guschin DY, Lee YL, Rupniewski I, Beausejour $\mathrm{CM}_{\text {, et }}$ al. An improved zinc-finger nuclease architecture for highly specific genome editing. Nat Biotechnol, 2007; 25: 778-785.

24. Mortazavi SM, Mohannadabadi MR, Khosravi-Darani K, Mozafari MR. Preparation of liposomal gene therapy vectors by a scalable method without using volatile or detergents. J Biotechnol. 2007;129:604-13.

25. Mozafari MR, Reed CJ, Rostron C. Prospects of anionic nanolipoplexes in nanotherapy: ransmission electron microscopy and light scattering studies. Micron. 2007:38(8):787-95.

26. Mussolino C, Morbitzer R, Lutge F, Dannemann N, Lahaye T, Cathomen T. A novel TALE nuclease scaffold enables high genome editing activity in combination with low toxicity. Nucleic Acids Res. 2011;39:9283-93.

27. Olbrich M, Rieger M, Reinert S, Alexander D. Isolation of osteoprogenitors from human jaw periosteal cells: a comparison of two magnetic separation methods. PLoS One. 2012;7:e47176.

28. Pennell DJ, Udelson JE, Arai AE, Bozkurt B, Cohen AR, Galanello R. Cardiovascular function and treatment in B-thalassemia major: a consensus statement from the American Heart Association. Circulation. 2013;128(3): 281-308.

29. Pierzchalski A, Mittag A, Bocsi J, Tarnok A. An innovative cascade system for simultaneous separation of multiple cell types. PLoS One. 2013;8(9):e74745.

30. Sabloff M, Chandy M, Wang Z, Logan BR, Ghavamzadeh A. HLA-matched sibling bone marrow transplantation for $\beta$-HYPERLINK thalassemia major. Blood. 2011:117(5):1745-50.

31. Sander JD, Dahlborg EJ, Goodwin MJ, Cade L, Zhang F, Cifuentes D, Curtin $\mathrm{SJ}$, et al. Selection-free zinc-finger-nuclease engineering by contextdependent assembly (CoDA). Nat Methods. 2011;8:67-9.

32. Sander JD, Joung JK. CRISPR-Cas systems for editing, regulating and targeting genomes. Nat Biotechnol. 2014;32(4):347-55. 
33. Sanjana NE, Cong L, Zhou Y, Cunniff MM, Feng G, Zhang F. A transcription activator-like effector toolbox for genome engineering. Nat Protoc. 2012;7:171-92.

34. Sürün D, Schwäble J, Tomasovic A, Ehling R, Stein S, Kurrle N, von Melchner H, Schnütgen F. High efficiency gene correction in hematopoietic cells by template-free crispr/cas9 genome editing. Mol Ther Nucleic Acids. 2018;10:1-8.

35. Tomlinson MJ, Tomlinson S, Yang XB, Kirkham J. Cell separation: terminology and practical considerations. J Tissue Engineering. 2013;4 https://doi.org/10.1177/2041731412472690.

36. Traxler EA, Yao Y, Wang YD, Wood KJ, Kurita R, Nakamura Y, Hughes JR, et al. A genome-editing strategy to treat $\beta$-hemoglobinopathies that recapitulates a mutation associated with a benign genetic condition. Nat Med. 2016;22(9):987-90.

37. Truong LN, Li Y, ShiLZ HPY, He J, Wang H, Razavian N, Berns MW, Wu X. Microhomology-mediated end joining and homologous recombination share the initial end resection step to repair DNA double-strand breaks in mammalian cells. PNAS. 2013:110(19):7720-5.

38. Voit RA, Hendel A, Pruett-Miller SM, Porteus MH. Nuclease-mediated gene editing by homologous recombination of the human globin locus. NucleicAcids Res. 2014;42:1365-78.

39. Waheed IN, Mnatib IM, Kadhimb AHH. In vitro study of adult bone marrow mesenchymal stem cells derived from albino rats and their cardiomyogenic Differentiation. Jordan J Biol Sci. 2010;4(3):185-92.

40. Welzel T, Radtke I, Meyer-Zaika W, Heumann R, Epple M. Transfection of cells with custom-made calcium phosphate nanoparticles coated with DNA. J Mater Chem. 2004:14:2213-7.

41. World Health Organization. Sickle-cell disease and other haemoglobin disorders. WHO Fact Sheet. 2011. p. 308. http://www.who.int/mediacentre/ factsheets/fs308/en.

42. Xu P, Tong Y, Liu XZ, Wang T, Cheng L, Wang B, Lv X, Huang Y, Liu D. Both TALENs and CRISPR/Cas9 directly target the HBB IVS2-654 (C>T) mutation in $\beta$-thalassemia-derived iPSCs. Sci Rep. 2015;5:12065.

\section{Publisher's Note}

Springer Nature remains neutral with regard to jurisdictional claims in published maps and institutional affiliations.

Ready to submit your research? Choose BMC and benefit from:

- fast, convenient online submission

- thorough peer review by experienced researchers in your field

- rapid publication on acceptance

- support for research data, including large and complex data types

- gold Open Access which fosters wider collaboration and increased citations

- maximum visibility for your research: over $100 \mathrm{M}$ website views per year

At $\mathrm{BMC}$, research is always in progress.

Learn more biomedcentral.com/submissions 